\title{
EFFECTS OF MICROFINANCE LENDING ON WORKING CAPITAL MANAGEMENT OF MICRO AND SMALL ENTERPRISES IN NAROK TOWN KENYA.
}

\author{
Cheruiyot K. Isaac ${ }^{1}$, Mary Bosire ${ }^{2}$ \\ ${ }^{1}$ Master scholar, Accounting and Finance dept., Egerton Uni., Kenya-15 \\ ${ }^{2}$ Lecturer, Accounting and Finance dept., Egerton Uni., Kenya - 15
}

\begin{abstract}
This study sought to establish the effects of MFI's lending on working capital management of micro and small businesses in Narok Town. The objectives of the study were to establish the effects of Microfinance lending on cash management, inventory management, receivables management and payable management of MSEs. The study used descriptive survey design and the target population comprised of 240 MSE's. Purposive sampling technique was used to select a sample of $71 \mathrm{MSE}$ 's from the population. Primary data were gathered for the study using face to face interviews with an aid of structured questionnaire. Reliability coefficient 0.7 and above was accepted. Descriptive statistics which includes percentages, frequencies, means, standard deviation and inferential statistics namely; $t$-test, Pearson product moment correlation and regressions were used to analyze the data. Test of significance was tested at $\alpha=0.1$. The Statistical Package for Social Science (SPSS) aided the data analysis. The study established that MFI's lending (cost of lending, loan period and loan size) positively affect working capital management (cash management, inventory management, receivables management and payable management) of MSEs in Narok Town.
\end{abstract}

Keywords: Working Capital Management, Micro Finance Lending and Micro and Small Enterprises

\section{Council for Innovative Research}

Peer Review Research Publishing System

Journal: International Journal Of Management \& Information Technology Vol . 10, No 9 editorsijmit@gmail.com 


\section{INTRODUCTION}

Microfinance traces its origins to 1976, when Yunus started a small microfinance scheme as an experiment in the rural areas of Bangladesh. The experiment evolved from its initial success into the Grameen Bank, the world's first microfinance institution, which popularized group lending, in which loans were issued to individual members of small, homogeneous groups, who collectively guarantee loans issued to their members. All members were barred from further access to credit in the case of default by one group member, providing strong incentives for the group to ensure repayment by each individual borrower (Roy, 2009).

Microfinance has now turned into an industry according to Robinson (2001). One of the key roles that microfinance plays in development is the bringing of access to financial services to the poor, to those who are neglected by the formal banking sector. Mainstream banks target clients that have collateral. The poor do not have assets to act as collateral, therefore they are ignored by the formal financial sector. These banks tend to be found in urban centers while the majority of the poor in the developing world live in rural areas, where financial services are not provided. Therefore, if MFIs are to fill this void they must reach the rural and semi-urban poor. However, according to most studies, microfinance is only reaching a small fraction of the estimated demand of the poor for financial services (Littlefield and Rosenberg, 2004).

Wanja 2009, argued that access to credit facilities is the main constraint for MSEs and limited access to capital to meet their operating working capital and long term investments. Therefore, this makes it difficult for them to achieve their performance in terms of liquidity and profitability hence leading to loss of business opportunities, and failure to grow in terms of size and financial resources (Badagawa, 2008). Sufficient working capital is important for the success and survival of small business which needs to be embrace to enhance performance and contribution to the economy, (Padachi, 2006).

The study sought to test the following hypothesis:

$\mathrm{H}_{\mathrm{O} 1}$ : MFIs lending does not have significant effect on MSEs cash management.

$\mathrm{H}_{\mathrm{O} 2:}$ MFIs lending does not have significant effect on MSEs inventory management.

$\mathrm{H}_{\mathrm{O} 3}$ : MFIs lending does not have significant effect on MSEs receivables management.

$\mathrm{H}_{\mathrm{O} 4}$ : MFIs lending does not have significant effect on MSEs payables management.

\section{LITERATURE REVIEW}

Gakure, Cheluget, Onyango and Keraro (2012) analyzed the relationship between working capital management and performance of 15 manufacturing firms from 2006 to 2010. They used secondary data from a sample of 18 companies. Pearson's correlation and regression analysis were used for the analysis. The results indicated that there is a strong negative relationship between firm's performance and liquidity of the firm. Gill, Biger and Mathur (2010) analyzed the relationship between working capital management and profitability of 88 American firms for a period of 3 years from 2005 to 2007 was selected. The data was analyzed using Pearson Bivariate Correlation Analysis and Weighted Least Squares (WLS) Regression techniques. They found statistically significant relationship between the cash conversion cycle and profitability, measured through gross operating profit.

Babajide (2012) investigated the effects of microfinance on micro and small business growth in Nigeria by examined the effects of different loan administration practices (in terms of loan size and tenor) on small business growth criteria. The result reported that firm level characteristics such as MFI size and MFI location, are found to have positive effect on enterprise growth. Beck et al (2010), provided the first attempt to understand MSE financing from the supply side. Based on a survey of 91 MFl's in 45 countries, the authors provided a characterization of MFI financing to MSEs and found that MFl's perceive the MSE segment to be highly profitable and serve them through a number of lending technologies and organizational setups. Rocha et al (2011) investigated the status of MFIs financing to MSEs in the Middle East and North Africa (MENA) based on survey of 139 banks in 16 countries. The authors found that in spite of positive perception of the attractiveness of the segment, the MSE sector in the region remains largely underserved.

$K^{\prime}$ Aol (2008), on the role of micro-finance in fostering women entrepreneurship in Kenya assessed the impact of Microfinance funding on women entrepreneurship in Kenya. The population consisted of women entrepreneurs who had benefited from four major Kenya Rural Enterprise Program (K-REP) microfinance schemes within Nairobi and Nyeri. The findings revealed that most of the respondents in this study reported that their business had expanded and their house hold income had increased significantly as a result of having taken microfinance loans from K-REP. The most significant impact evident among the women entrepreneurs involved in farming activities was that the number cattle they owned had doubled after taking the loan.

\section{METHODOLOGY}

This study used a descriptive survey design. The purpose of employing the descriptive survey design is to describe the nature of condition as it takes place and explore the cause or causes of a particular condition. The target population of the study was 240 MSEs operating in Narok Town. The study used purposive sampling to administer the questionnaire. The study was purposely interested in the MFIs clients because they had relevant information on provision of microfinance. The study used face to face interviews with an aid of questionnaire to collect data. The questionnaire was structured. Data collected was analyzed using both descriptive statistic and regressions. Data was analyzed for means, frequencies, percentages and standard deviations using descriptive statistic, whereas regression was used to ascertain the relationship between MFIs lending and working capital management variables of MSEs. 


\section{DATA ANALYSIS, PRESENTATION AND DISCUSSION}

\subsection{Effect of MFls lending on cash management of MSEs}

The first objective of the study was to establish the effect of MFIs lending (cost of lending, loan period and loan size) on cash management of MSEs. The study used Pearson Correlation to establish the relationship between MFIs lending and cash management

Table 1: Relationship between MFls lending and cash management

\begin{tabular}{lll}
\hline & & Cash Management \\
\hline \multirow{3}{*}{ MFIs lending } & Pearson Correlation & $0.676^{\prime \prime}$ \\
& Sig. (1-tailed) & 0.000 \\
& $\mathrm{~N}$ & 59 \\
\hline
\end{tabular}

** Correlation is significant at the 0.1 level (1-tailed).

Source: Field Data (2015)

The results revealed that there was a strong statistically significant positive relationship of $(r=0.676, p<0.1)$ between MFIs lending and cash management. Consequently, the $\mathrm{H}_{0} 1$ which stated that there is no statistically significant relationship between MFIs lending and cash management was rejected and the alternative hypothesis which states that there is statistically significant relationship between MFIs lending and cash management was accepted.

Table 2: Analysis to determining the Effect of MFIs lending on MSEs cash management in Narok Town.

\section{Model Summary}

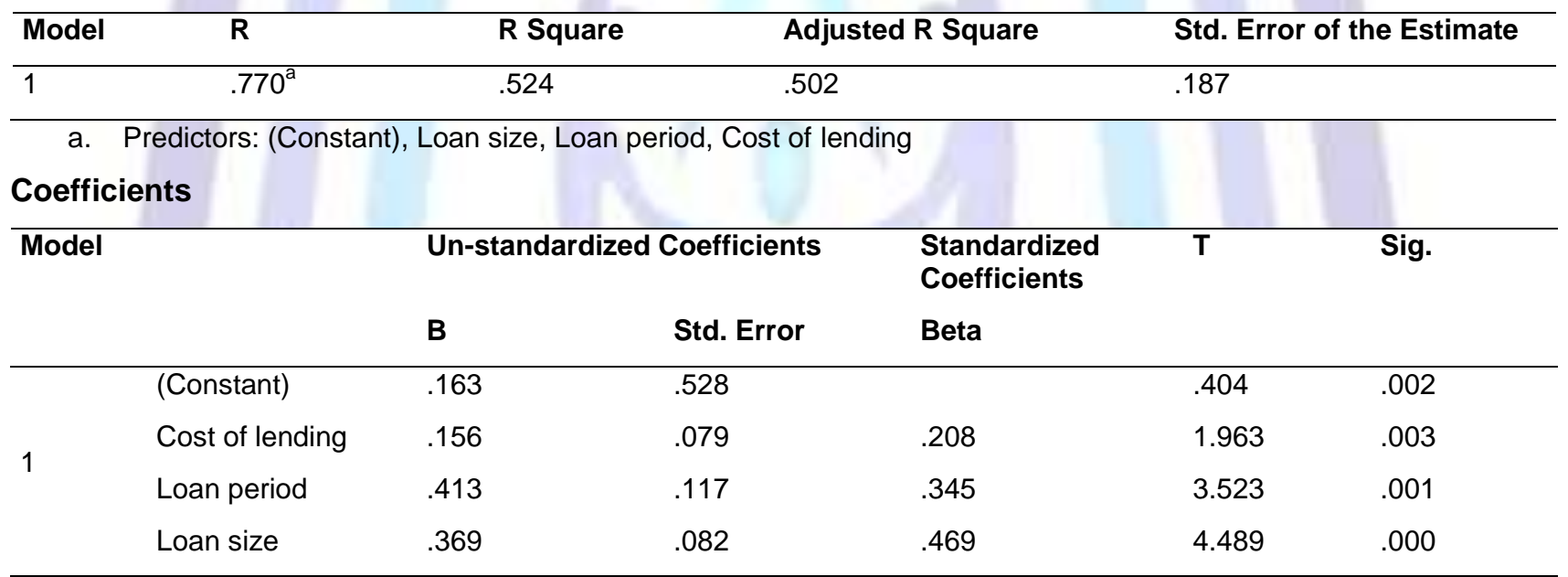

a. Dependent Variable: cash management.

Source: Field Data (2015)

Table 2, indicates that MFIs lending (Cost of lending, Loan period and Loan size) accounted for $52.4 \%$ of the variation in on MSEs cash management in Narok Town $\left(R^{2}=0.524\right)$. The un-standardized beta coefficients indicate that Cost of lending $(\beta=0.156, p<0.1)$, Loan period $(\beta=0.413, p<0.1)$ and Loan size $(\beta=0.369, p<0.1)$ were the strongest predictors of MSEs cash management in Narok Town. This suggests that, all the MFls lending (Cost of lending, Loan period and Loan size) has an effect on MSEs cash management in Narok Town. Therefore there was statistically significant relationship between MFIs lending (Cost of lending, Loan period and Loan size) and MSEs cash management.

\section{Multiple Regression Model}

$\mathrm{Y}_{1}=0.163+0.156 \mathrm{X}_{1}+0.413 \mathrm{X}_{2}+0.369 \mathrm{X}_{3}+\varepsilon$

\section{Interpretation}

When there is $1 \%$ increase in cost of lending, MSEs cash management will increase by $0.156 \%$ and when there is $1 \%$ increase in loan period, MSEs cash management will increase by $0.413 \%$. When there is $1 \%$ increase in loan size, MSEs cash management will increase by $0.369 \%$. The above multiple regression model indicate that the MFls lending positively effect MSEs cash management in Narok town. 


\subsection{Relationship between MFls lending and inventory Management}

The second objective of the study was to establish the effect of MFIs lending (cost of lending, loan period, and loan size) on inventory management of MSEs. The study used Pearson Correlation to establish the relationship between MFIs lending and inventory Management.

Table 3: Relationship between MFIs lending and Inventory Management

\begin{tabular}{lll}
\hline & & Inventory Management \\
\hline \multirow{3}{*}{ MFIs lending } & Pearson Correlation & $0.425^{\prime \prime}$ \\
& Sig. (1-tailed) & 0.000 \\
& $\mathrm{~N}$ & 60 \\
\hline
\end{tabular}

** Correlation is significant at the 0.1 level (1-tailed).

Source: Field Data (2015)

Based on the results the study revealed that there was a moderate statistically significant positive relationship of $(r=$ $0.425, \mathrm{p}<0.1$ ) between MFIs lending and inventory management. $\mathrm{H}_{0} 1$ which stated that there is no statistically significant relationship between MFIs lending and inventory management was rejected and the alternative hypothesis which states that there is statistically significant relationship between MFIs lending and inventory management was accepted.

Table 4.: Analysis to determine the Effect of MFIs lending on MSEs inventory management in Narok Town

Model Summary

\begin{tabular}{lllll}
\hline Model & $\mathbf{R}$ & R Square & Adjusted R Square & Std. Error of the Estimate \\
\hline 1 & $.735^{\mathrm{a}}$ & .589 & .546 & .189
\end{tabular}

a. Predictors: (Constant), Loan size, Loan period, Cost of lending

\section{Coefficients}

\begin{tabular}{lllllll}
\hline Model & & \multicolumn{2}{l}{ Un-standardized Coefficients } & $\begin{array}{l}\text { Standardized } \\
\text { Coefficients } \\
\text { Beta }\end{array}$ & T & Sig. \\
\hline \multirow{2}{*}{1} & B & Std. Error & .769 & & 1.630 & .004 \\
& (Constant) & .254 & .116 & .323 & 2.442 & .000 \\
& Cost of lending & .234 & .171 & .109 & .890 & .000 \\
& Loan period & .202 & .120 & .150 & 1.148 & .001
\end{tabular}

a. Dependent Variable: inventory management.

Table 4, indicates that MFIs lending (Cost of lending, Loan period and Loan size) accounted for $58.9 \%$ of the variation in on MSEs inventory management in Narok Town $\left(R^{2}=0.589\right)$. The un-standardized beta coefficients indicate that Cost of lending $(\beta=0.234, p<0.1)$, Loan period $(\beta=0.202, p<0.1)$ and Loan size $(\beta=0.138, p<0.1)$ were the strongest predictors of MSEs inventory management in Narok Town. This suggests that, all the MFIs lending (Cost of lending, Loan period and Loan size)has an effect on MSEs inventory management in Narok Town. Therefore there was statistically significant relationship between MFIs lending (Cost of lending, Loan period and Loan size) and MSEs inventory management.

\section{Multiple Regression Model}

$\mathrm{Y}_{2}=0.254+0.234 \mathrm{X}_{1}+0.202 \mathrm{X}_{2}+0.138 \mathrm{X}_{3}+\varepsilon$

\section{Interpretation}

When there is $1 \%$ increase in cost of lending, MSEs inventory management will increase by $0.234 \%$ andwhen there is $1 \%$ increase in loan period, MSEs inventory management will increase by $0.202 \%$. When there is $1 \%$ increase in loan size, MSEs inventory management will increase by $0.138 \%$. The above multiple regression model indicate that the MFIs lending positively effect MSEs inventory management in Narok town.

\subsection{Relationship between MFIs Lending and Receivable Management}

The third objective of the study was to establish the effect of MFIs lending (cost of lending, loan period, and loan size) on receivable management of MSEs. The study used Pearson Correlation to establish the relationship between MFIs lending and receivable management. 
Table 5: Relationship between MFIs lending and Account Receivable Management

\begin{tabular}{lll}
\hline & & Receivable Management \\
\hline \multirow{3}{*}{ MFIs lending } & Pearson Correlation & 0.729 \\
& Sig. (1-tailed) & 0.000 \\
& $\mathrm{~N}$ & 60 \\
\hline
\end{tabular}

${ }^{* *}$ Correlation is significant at the 0.1 level (1-tailed). P- Significant level

Source: Field Data (2015)

Based on the results the study revealed that there was a strong statistically significant positive relationship of $(r=0.729, \mathrm{p}$ $<0.1$ ) between MFIs lending and receivable management. $\mathrm{H}_{0} 1$ which stated that there is no statistically significant relationship between MFIs lending and receivable management was rejected and the alternative hypothesis which states that there is statistically significant relationship between MFIs lending and receivable management was accepted.

Table 6: Analysis to determine the Effect of MFIs lending on MSEs receivable management in Narok Town.

Model Summary

\begin{tabular}{lllll}
\hline Model & R & R Square & Adjusted R Square & Std. Error Of The Estimate
\end{tabular}

\begin{tabular}{|c|c|c|c|c|c|c|}
\hline 1 & $.754^{\mathrm{a}}$ & & .545 & & 279 & \\
\hline \multicolumn{7}{|c|}{ A. Predictors: (Constant), Loan size, Loan period, Cost of lending } \\
\hline \multicolumn{7}{|c|}{ Coefficients } \\
\hline \multirow[t]{2}{*}{ Model } & & \multicolumn{2}{|c|}{ Un-standardized Coefficients } & Standardized & $\mathbf{T}$ & Sig. \\
\hline & & B & Std. Error & Beta & & \\
\hline \multirow{4}{*}{1} & (Constant) & .246 & .144 & & 4.003 & .000 \\
\hline & Cost of lending & .142 & .112 & .466 & 4.827 & .000 \\
\hline & Loan period & .130 & .165 & .070 & 4.788 & .003 \\
\hline & Loan size & .217 & .116 & .424 & 4.452 & .000 \\
\hline
\end{tabular}

a. Dependent Variable: Receivable Management.

Table 6, indicates that MFIs lending (Cost of lending, Loan period and Loan size) accounted for $56.8 \%$ of the variation in on MSEs Account Receivable Management in Narok Town $\left(R^{2}=0.568\right)$. The un-standardized beta coefficients indicate that Cost of lending $(\beta=0.142, p<0.1)$, Loan period $(\beta=0.130, p<0.1)$ and Loan size $(\beta=0.217, p<0.1)$ were the strongest predictors of MSEs Account Receivable Management in Narok Town. This suggests that, all the MFIs lending (Cost of lending, Loan period and Loan size) has an effect on MSEs Receivable Management in Narok Town. Therefore there was statistically significant relationship between MFIs lending (Cost of lending, Loan period and Loan size) and MSEs Receivable Management.

Thus the MFIs lending will be high in MSEs in Narok town that adopted MSEs Receivable Management.

\section{Multiple Regression Model}

$\mathrm{Y}_{3}=0.246+0.142 \mathrm{X}_{1}+0.130 \mathrm{X}_{2}+0.217 \mathrm{X}_{3}+\varepsilon$

\section{Interpretation}

When there is $1 \%$ increase in cost of lending, MSEs receivable management will increase by $0.142 \%$ and when there is $1 \%$ increase in loan period, MSEs receivable management will increase by $0.130 \%$. When there is $1 \%$ increase in loan size, MSEs receivable management will increase by $0.217 \%$. The above multiple regression model indicate that the MFIs lending positively effect MSEs receivable management in Narok town.

\subsection{Relationship between MFIs lending and Payable Management}

The fourth objective of the study was to establish the effect of MFIs lending (cost of lending, loan period, and loan size) on payable management of MSEs. The study used Pearson Correlation to establish the relationship between MFIs lending and Payable Management. 
Table 7: Relationship between MFls lending and Payable Management

\begin{tabular}{lll}
\hline & & Payable Management \\
\hline \multirow{3}{*}{ MFIs lending } & Pearson Correlation & 0.459 \\
& Sig. (1-tailed) & 0.000 \\
& $\mathrm{~N}$ & 60 \\
\hline
\end{tabular}

** Correlation is significant at the 0.1 level (1-tailed).

Source: Field Data (2015)

The results revealed that there was a moderate statistically significant positive relationship of $(r=0.459, p<0.1)$ between MFIs lending and payable management. Consequently, the $\mathrm{H}_{0} 1$ which stated that there is no statistically significant relationship between MFIs lending and account payable management was rejected and the alternative hypothesis which states that there is statistically significant relationship between MFIs lending and payable management was accepted.

Table 8: Results of Multiple Regression Analysis determining the Effect of MFIs lending on MSEs payable management in Narok Town.

Model Summary

\begin{tabular}{lllll}
\hline Model & $\mathbf{R}$ & $\mathbf{R}$ Square & Adjusted R Square & Std. Error of the Estimate \\
\hline 1 & $.841^{\mathrm{a}}$ & .693 & .255 & .199 \\
\hline
\end{tabular}

a. Predictors: (Constant), Loan size, Loan period, Cost of lending

\section{Coefficients}

\begin{tabular}{|c|c|c|c|c|c|c|}
\hline \multirow[t]{2}{*}{ Model } & & \multicolumn{2}{|c|}{ Un-standardized Coefficients } & \multirow{2}{*}{$\begin{array}{l}\text { Standardized } \\
\text { Coefficients } \\
\text { Beta }\end{array}$} & \multirow[t]{2}{*}{$\mathbf{T}$} & \multirow[t]{2}{*}{ Sig. } \\
\hline & & B & Std. Error & & & \\
\hline \multirow{4}{*}{1} & (Constant) & .207 & .797 & & .511 & .000 \\
\hline & Cost of lending & .230 & .120 & .339 & 2.746 & .002 \\
\hline & Loan period & .254 & .177 & .357 & 3.127 & .003 \\
\hline & Loan size & .126 & .124 & .026 & .213 & .000 \\
\hline
\end{tabular}

a. Dependent Variable: Account payable management.

Table 8, indicates that MFIs lending (Cost of lending, Loan period and Loan size) accounted for $69.3 \%$ of the variation in on MSEs payable management in Narok Town $\left(R^{2}=0.693\right)$ The un-standardized beta coefficients indicate that Cost of lending $(\beta=0.230 p<0.1)$, Loan period $(\beta=0.254, p<0.1)$ and Loan size $(\beta=0.126, p<0.1)$ were the strongest predictors of MSEs Account payable management in Narok Town. This suggests that, all the MFIs lending (Cost of lending, Loan period and Loan size) has an effect on MSEs payable management in Narok Town. Therefore there was statistically significant relationship between MFIs lending (Cost of lending, Loan period and Loan size) and MSEs payable management.

Thus the MFIs lending will be high in MSEs in Narok town that adopted MSEs payable management.

\section{Multiple Regression Model}

$\mathrm{Y}_{4}=0.207+0.230 \mathrm{X}_{1}+0.254 \mathrm{X}_{2}+0.126 \mathrm{X}_{3}+\varepsilon$

\section{Interpretation}

When there is $1 \%$ increase in cost of lending, MSEs payable management will increase by $0.230 \%$ and when there is $1 \%$ increase in loan period, MSEs account payable management will increase by $0.254 \%$. When there is $1 \%$ increase in loan size, MSEs payable management will increase by $0.126 \%$. The above multiple regression model indicate that the MFIs lending positively effect MSEs payable management in Narok town.

\section{CONCLUSIONS}

In conclusion, it is evident that adoption of MFI's lending is likely to significantly improve/enhance the working capital management of MSEs in Narok Town. Thus MFI's lending have a positive effect on working capital management of MSEs.

\section{REFERENCES}

1. Badagawa, M.W,(2008), "Measuring microenterprise profits: ",Journal of Development Economics, 88(1), 19-31., Journal of Development Economics, 88(1), 19-31. 
2. Babajide, A (2011). Effects of Microfinance on Micro and Small Enterprises (MSEs) Growth in Nigeria. Asian Economic and Financial Review, 2(4): 1-14

3. Beck, T., A. Demircuc-Kunt and M. S. Martinez Peria,2010.'Bank Finance for Journal of financial services research Vol 50, No. 20

4. Cabbar, Y. (2000) Black-Sea Economic Cooperation Workshop on Internet, E-commerce and SMEs. Speech delivered at the Heaquarters of the BSEC Permanent International Secretariat, Istanbul, Turkey, 2 May. Available at [www.unce.org]. Accessed [01/10/03].

5. Gakure, R., Cheluget, J. K., Onyango, J. A., \&Keraro, V. (2012). Working capital management and profitability of manufacturing firms listed at the Nairobi stock exchange. Prime Journal of Business Administration and Management, 2(9), 680- 685.

6. Gill, A., Biger, N., \& Mathur, N. (2010). The relationship between working capital management and profitability: Evidence from the United States. Business and Economics Journal, 2010, 1-9.

7. K'aolg, O. (2008). The role of microfinance in fostering women entrepreneurship in Kenya. Nairobi. Kenya Rural Enterprise Program (K-REP), Nairobi, Vol 80: 50-60

8. Littlefield, E. and Rosenberg, R. (2004), 'Distribution, growth, and performance of microfinance institutions in Africa, Asia, and Latin America', IFPRI, FCND, Discussion Paper n¹14, June, 34 p.

9. Nwanna, I., (2000). Financial Accessibility and rural sector development. Savings and Development 19(4): 453-491

10. Padachi, K. (2006). Trends in Working Capital Management and its Impact on Firms' Performance: An Analysis of Mauritian Small Manufacturing Firms. International Review of Business Research Papers. $2(2), 45-58$.

11. Robinson, M.S., 1996, Addressing some key questions on finance and poverty, Journal of International Development 8, 153-163.

12. Rocha Q. U., Pedro \& García-T, Pedro J. (2011).MFIs financing to MSEs in the Middle East and North Africa (MENA). International Small Business Journal, Vol. 14 No. 2, pp. 52-68.

13. Roy, M.K. (2009). SFDF Model: A Means to Improve Rural Livelihood. Dhaka: The Bangladesh Observer, p.

14. Wanja, K. (2009). Institutional impediments to access to credit by micro and small enteprises in Kenya. Discussion paper no. 026/2000. 